\title{
Prospects of organic acids as safe alternative to antibiotics in broiler chickens diet
}

\author{
Rifat Ullah Khan ${ }^{1} \cdot$ Shabana $\mathrm{Naz}^{2} \cdot$ Fazal Raziq $^{3} \cdot$ Qudratullah Qudratullah $^{4} \cdot$ Nazir Ahmad Khan $^{5} \cdot$ Vito Laudadio $^{6}$. \\ Vincenzo Tufarelli ${ }^{6}$ (D) Marco Ragni $^{7}$
}

Received: 4 December 2021 / Accepted: 11 February 2022 / Published online: 23 February 2022

(c) The Author(s) 2022

\begin{abstract}
Genetically, modern broilers are fast-growing birds which attain the market age at the age of 5 weeks. To maintain optimum production, antibiotics have been commonly included in the diets as growth promoters. However, due to the increase in antimicrobial resistance, their uses have been banned worldwide. To keep the optimum level of production and health in broiler industry, the use of alternative growth promoters such as probiotics, prebiotics, enzymes, and organic acids has been proposed. Chemically, organic acids are weak acids and only partially dissociate. They are considered safe and have been used for preservation of food for centuries. Nowadays, organic acids have been reported for antibacterial, immune potentiating, and growth promoters in broilers. In this review, the effects of dietary inclusion of organic acids on growth, nutrient digestibility, intestinal integrity, immune system, and antibacterial activity in broilers are discussed.
\end{abstract}

Keywords Organic acid $\cdot$ Broiler $\cdot$ Growth $\cdot$ Immunity $\cdot$ Health

\section{Introduction}

Feed additives are now considered essential for the optimum performance and productivity in modern poultry production (Shahid et al. 2015). In the past, antibiotics have been used

Responsible Editor: Philippe Garrigues

Vincenzo Tufarelli

vincenzo.tufarelli@uniba.it

1 College of Veterinary Sciences, Faculty of Animal Husbandry and Veterinary Sciences, The University of Agriculture, Peshawar, Pakistan

2 Department of Zoology, Government College University, Faisalabad, Pakistan

3 Livestock and Dairy Development, Peshawar, Pakistan

4 Department of Surgery and Pet Centre, Cholistan University of Veterinary and Animal Sciences, Bahawalpur, Pakistan

5 Department of Animal Nutrition, Faculty of Animal Husbandry \& Veterinary Sciences, The University of Agriculture, Peshawar, Pakistan

6 Department of DETO, Section of Veterinary Science and Animal Production, University of Bari 'Aldo Moro', Valenzano, Bari, Italy

7 Department of Agro-Environmental and Territorial Science, University of Bari ‘Aldo Moro', Bari, Italy as growth promoters for enhanced production and balancing intestinal flora (Garcia et al. 2007; Abudabos et al. 2016; Haulisah et al. 2021). Antibiotic-resistant bacteria could easily be transmitted from animals to the human through food chain (Chowdhury et al. 2009; Khan et al. 2016a). The use of subtherapeutic level of antibiotics has a viable role in enhancing poultry production for many years. However, this practice was discouraged due to the emergence of antibiotic resistance of animal and human pathogens. The European Union was the first organization which indicated its intention to withdraw the use of antibiotic in 2006. The search for an alternative was therefore suggested to provide suitable alternative role which could maintain the growth and feed efficiency in the farm animals (Scicutella et al. 2021).

Recently, the use of antibiotics as growth promoters has been banned due to the emerging resistance against microbes and their residues in meat and egg (Cakir et al. 2008; Dhama et al. 2015; Ullah et al. 2022). Due to the ban on the use of antibiotics in poultry production, there are compelling reasons to use other alternatives to maintain optimum poultry production (Raza et al. 2016; Chand et al. 2016; Tehseen et al. 2016; Hafeez et al. 2021). Therefore, there is a need to search for alternatives, especially in view of recent withdrawal by the European Union (Khan et al. 2012a; Alzawqari et al. 2016; Abudabos et al. 2018). 
Several feed additives have been proposed such as probiotic (Khan and Naz 2013; Khan et al.2013a, b, 2014a, b; Alam et al. 2020; Shah et al. 2020), prebiotics (Chand et al.2016, 2019; Tufail et al. 2019; Haq et al. 2020), enzymes (Abd El-Hack et al. 2018; Sultan et al. 2019; Alam et al. 2020; Jabbar et al. 2021a, b), and herbs (Khan et al. 2012a, b, c, d; Mushtaq et al. 2013; Dhama et al. 2014; Alzawqari et al. 2016; Hafeez et al. 2020a, b, c; Ahmad et al. 2020; Chand et al. 2021; Israr et al. 2021; Khan et al. 2021a, b; Shuaib et al. 2021a, b), which have been reported in poultry (Fig. 1) and illustrated by Gadde et al. (2017). Among these, the organic acids (propionic acid, formic acid, citric acid, acetic acid) are promising alternatives. Their inclusion in the broiler feed has been shown to enhance the feed intake, growth, and feed efficiency.

Acidifiers play a key role in the preservation of feed stuff without antibiotics. For centuries, organic acids have been used as feed preservative due to their strong antibacterial and antifungal properties (Hernandez et al. 2006). For effective livestock production, a constant supply of highquality feed should be available all year. Even in hygienic settings, variables like high moisture and a warm atmosphere might encourage the growth of fungi, yeast, or bacteria, reducing the nutritional content of the feed by metabolizing its carbohydrates and protein. Benzoic acid, acetic acid, and their salts, such as sodium benzoate and sodium acetate, can be used as feed preservative (Pearlin et al. 2020). Organic acids or salts can be added to poultry feed at a rate of $0.5 \mathrm{~kg} /$ ton for mold control and 2.5-3.0 kg/ton for $\mathrm{pH}$ decrease and Salmonella control (Banupriya et al. 2016). Organic acids individually or their combinations are usually considered safe and perform similar functions like antibiotics (Adil et al. 2010). The antimicrobial mechanism of organic acid has been suggested to the lowering of $\mathrm{pH}$ of the gut, thereby limiting the growth of the bacteria less tolerant to acid $\mathrm{pH}$ (Hernandez et al. 2006). The antimicrobial activity of the organic acid is linked with either simple monocarboxylic acid such as butyric acid, propionic acid, acetic acid and formic acid, or carboxylic acid having a hydroxyl group such as tartaric acid, citric acid, malic acid, and lactic acid. Most acids having antimicrobial activity have a pKa value between 3 and 5. The molecular weight, pKa value, shape (undissociated or dissociated), and particular antibacterial action (targeted microorganism) all influence organic acid efficiency (Aljumaah et al. 2020). Chemically, organic acids are weak acids and dissociate only partially. Most of the organic acids are available as sodium, potassium, and calcium salts with varying physical and chemical characteristics. The magnitude of antimicrobial activity of an acid depends upon its concentration and $\mathrm{pH}$ (Chaveerach et al. 2004). Moreover, each of the acid has a specific spectrum of antimicrobial activity. For example, lactic acid is more effective against bacteria, whereas sorbic acid acts is known for its anti-mold activity (Dibner and Buttin 2002). Some other organic acids have a wide range of the spectrum. For example, formic acid and propionic acid are antibacterial and antifungal. Microencapsulation is another option, as the inert film that surrounds the organic acid particles allows for a more efficient release of these compounds (Galli et al. 2021). As a result, the therapeutic activity is spread throughout the gut. In the previous reviews, organic acids in poultry have several deficiencies. The current review provides some new aspects not covered by previous reviews. For example, Scicutella et al. (2021) reported a combination
Fig. 1 Example of some alternatives to antibiotics used in broiler production

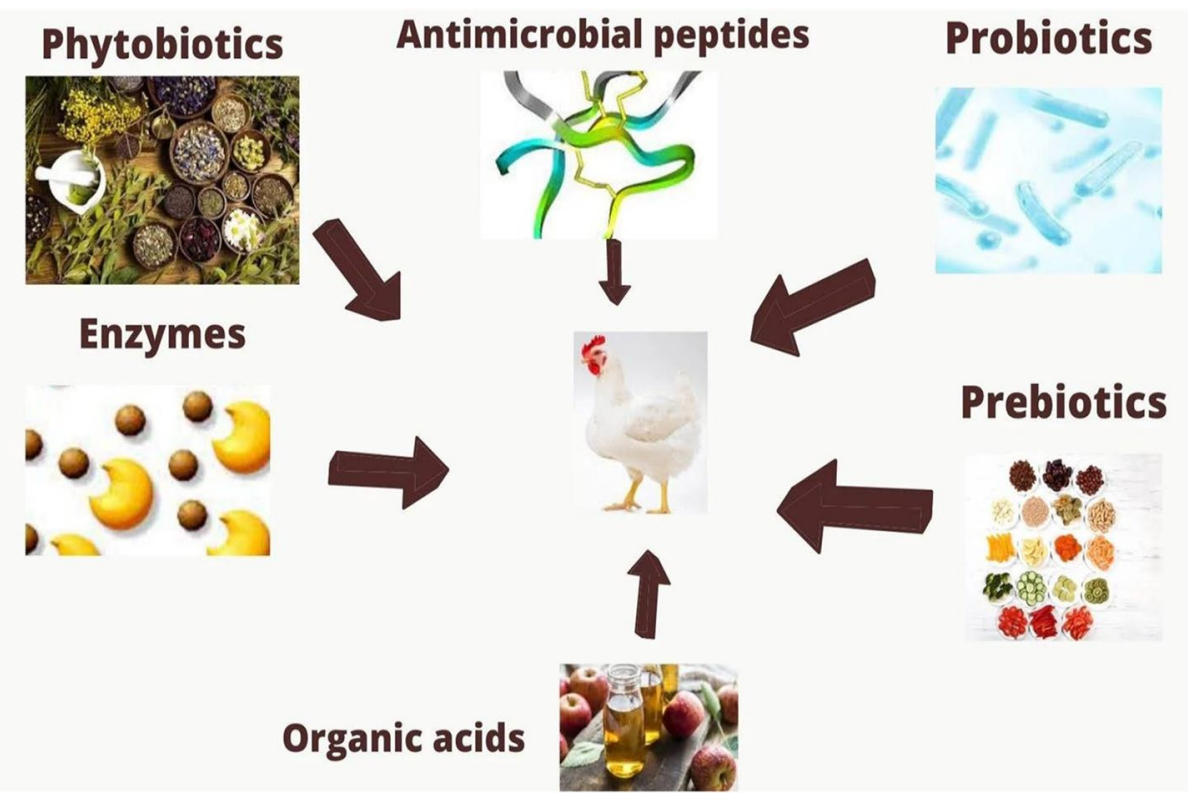


of phenolic compounds and organic acids. Similarly, other previous reviews have not covered some of the important aspects such as growth and nutrient digestibility. Important aspect of the present review is that it has described in detail the mechanism of action of organic acid producing benefits to the poultry producers.

\section{Classification and uses of organic acids}

Organic acids are composed of an organic carboxylic acid such as amino acids and fatty acids having R-COOH structure. Only limited numbers of these acids have an effect on the gut microflora. Organic acids have long been used as additive for the reduction in food deterioration and prolonging the shelf life of food commodities especially perishable food ingredients. Organic acid is generally composed of saturated straight-chain monocarboxylic acids or their derivatives (Ricke, 2003). Some of the acids, such as butyrate, propionate, and acetate, are produced in the GIT of the animals where the anaerobic environment is predominant. Organic acids were originally added in the food animal industry as an antifungal agent; however, in the past, there is evidence that the different acids such as formic acid and propionic acids have been used for their antibacterial activities against contaminated food-borne pathogens especially Salmonella species (Ricke, 2003). Some of the examples of the positive effects of organic acids in broilers are given in Tables 1 and 2.

\section{Growth-promoting effect}

In most of the instances, growth-promoting effects have been reported in broiler in response to organic acid supplementation. The improved growth-promoting effects of the organic acids could possibly be due to the better feed utilization, the reduction in pathogenic microbial load, and the provision of a suitable environment for the growth-enhancing bacteria (Khan et al. 2016a; BaghbanKanani et al. 2019). Chowdhury et al. (2009) found that supplementation of $0.5 \%$ citric acid improved feed intake, growth, carcass yield, and bone ash in broiler. Abdel-Fattah et al. (2008) reported that live body weight was improved in chicks fed a diet supplemented with acetic acid, citric acid, and lactic acid. Moghadam et al. (2006) found that feed consumption in broiler improved when supplemented with citric acid. Improved feed intake and feed efficiency were also reported by Atapattu and Nelligaswatta (2005). Nezhad et al. (2007) reported that feed efficiency improved in broiler fed with citric acid. Vogt et al. (1981) found that supplementation of ascorbic, malic acid, and tartaric acid increased weight gain and feed efficiency. Panda et al. (2009) reported improved broiler weight in response to

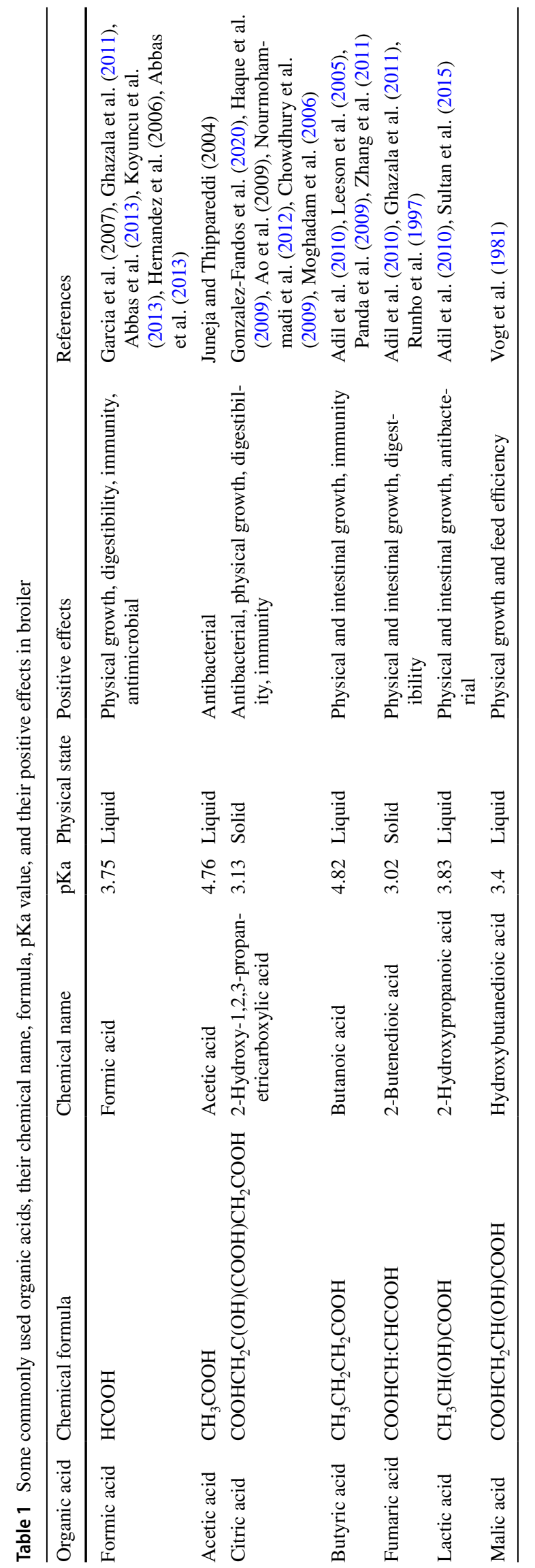


Table 2 Example of type of organic acid, dose, and effect against different pathogens in broilers

\begin{tabular}{lllll}
\hline Organic acid & Dose & Effects & References \\
\hline Formic acid + sodium formate & $0.9 \%$ & Antimicrobial effect against Salmonella typhimurium & Adhikari et al. (2020) \\
Mainly formic acid & $0.5 \mathrm{~kg} / \mathrm{ton}$ & Antimicrobial effect against Campylobacter coli & Mortada et al. (2020) \\
Formic + propionic acids and their salts & $0.1,0.02,0.04 \%$ & Antimicrobial effect against E. coli K88 & Emami et al. (2017) \\
Wheat bran fermented fatty acids & $0.1 \%$ & Antimicrobial against Salmonella & Vermeulen et al. (2017) \\
Medium chain fatty acids & Unknown & Antimicrobial effect against Salmonella typhimurium & Abudabos et al. (2017) \\
Short and medium chain fatty acids & $0.5-2.5 \mathrm{~g} / \mathrm{kg}$ & Antimicrobial effect against & Kumar et al. (2021) \\
\hline
\end{tabular}

$0.4 \%$ butyrate in comparison with antibiotic dose. Similarly, improved broiler weight and feed efficiency have been reported by other researchers (Leeson et al. 2005; Adil et al. 2010; Rodjan et al. 2017; Yang et al. 2018; Araujo et al. 2019; Nguyen and Kim 2020; Sureshkumar et al. 2021). Adhikari et al. (2020) also reported improved growth performance in Salmonella typhimurium-infected broilers in response to supplementation of $0.9 \%$ organic acid. Sabour et al. (2019) fed a diet supplemented with a combination of sodium butyrate, citric acid, phosphoric acid, acetic acid, propionic acid, formic acid, and lactic acid and reported improved growth performance in broilers. Emami et al. (2017) found improved growth performance in broilers infected with $E$. coli $K 88$, which was attributed to the enhanced nutrient digestibility.

The improved performance of broilers in response to the supplementation of organic acid is due to enhanced digestibility of energy and protein contents of the feed and reduction of microbial pathogens, improving the immunity, lowering the infectious level, and reducing the ammonia and other harmful metabolites (Khan et al. 2016a). The improved FCR could be probably due to the lower feed intake and better utilization of nutrients resulting in a higher weight gain in broiler supplemented with organic acids. In addition, the undissociated organic acid could easily penetrate the lipid bi-layers of the cell membrane of the molds and bacteria. Inside the cell, the proton is released by the organic acid in the presence of the alkaline environment, resulting in the reduction of the intracellular pH (Hernández et al. 2006). This process is followed by the enzymatic reaction forcing the bacterial cell to release proton and the accumulation of intracellular anion. Other beneficial impacts include the release of digestive enzymes and microbial phytase activity, pancreatic secretion, and proliferation of intestinal cells (Dibner and Buttin 2002).

The literature reports on how the dietary fermentable fiber fraction may be used to create bioactive fatty acids in the animal gut, which have an antibacterial impact, as one of the most current techniques to supplement diets with organic acids (Yudiarti et al. 2020). Wheat bran, a by-product of wheat milling, was added to feed to see how effective it was against Salmonella in terms of percent and particle size. The genes that control Salmonella pathogenicity were downregulated as a result of a quick fermentation process that generated butyric acid (Scicutella et al. 2021). In addition, organic acids have been used to improve the meat quality. In this way, a dose of $300 \mathrm{mg} / \mathrm{kg}$ glycerol monolaurate can exert positive effect on improving the nutritional quality of meat (Fortuoso et al. 2019).

\section{Antimicrobial effect of organic acid}

In poultry production, organic acids have been used as a tool to reduce pathogenic bacteria. The important pathogenic bacteria colonizing the intestinal tract include Escherichia coli, Campylobacter, and Salmonella. Many of the reports have documented positive effects of organic acids on the reduction of these pathogenic bacteria in drinking water and the part of the gastrointestinal tract (GIT), ultimately leading to improved feed utilization and growth performance (Khan et al. 2016b). Koyuncu et al. (2013) found a reduction in Salmonella in feed treated for 5 days with $1 \%$ formic acid. Gonzalez-Fandos et al. (2020) reported that citric acid solution reduced the growth of Listeria monocytogenes on poultry legs stored at $4{ }^{\circ} \mathrm{C}$ for 8 days. Adhikari et al. (2020) found that addition of $0.9 \%$ organic acid (mainly sodium format) in the diet of broilers resulted in reversing the Salmonella typhimurium colonization in broiler chickens. Mortada et al. (2020) concluded that organic acid (formic acid, cinnamaldehyde) significantly inhibited the proliferation of Campylobacter coli population in the in vitro study although its effect on cecal load and carcass surface remained no significant. Kumar et al. (2021) reported that organic acid is effective in decreasing cecal Clostridium perfringens shedding in broilers during experimental induction of the infection. Beneficial bacteria were increased while E. coli infestation decreased in response to organic acid supplementation in a 35-day experiment (Emami et al. 2017). Improved beneficial bacterial profile (increased Lactobacillus spp.) was also found to be improved in response to organic acid in broilers in several studies (Rodjan et al. 2017; Nguyen and Kim 2020; Sureshkumar et al. 2021).

An important source of Campylobacter infection is poultry products, since horizontal and vertical transmission of Campylobacter are unlikely to occur. In addition, 
Campylobacter can survive in drinking water for a long time (Chaveerach et al. 2004). Chaveerach et al. (2004) reported that the signs of Campylobacter infection in the gut disappeared by drinking acidified water. The antibacterial activity of the organic acids is not fully understood. The literature indicated that the effects of different organic acids depend on the type of organism, chemical composition, animal species, exact location in the intestines, and buffering capacity. The positive effects of antibacterial activity of organic acid have been linked with the physical chemistry of the acid, bacterial species, media composition, and growth conditions (Ricke 2003). The use of citric acid improves the development of Lactobacillus spp. in the gut and inhibits the growth and proliferation of pathogenic bacteria such as Salmonella and Escherichia coli by activating the proteolytic enzymes, absorption of minerals, reduction of ammonia and growthdepressing microbial metabolites, and stimulation of feed intake (Chowdhury et al. 2009).

The mechanism of action of organic acids is quite different from that of inorganic acid. According to Dibner and Buttin (2002), the mechanism of action of organic acids is linked with its special characteristic of dissociation. Under low $\mathrm{pH}$, the acid is more available in the dissociated form. The undissociated form of organic acids is more lipophilic in nature and can easily diffuse into the cell membrane of bacteria and molds (Fig. 2). The low pH inside the cell causes disruption of the enzymatic reaction and transport system (Scicutella et al. 2021). In addition, the low pH disrupts the energy generation process, which ultimately leads to prevention of the bacterial cell proliferation and growth resulting in some degree of bacteriostasis (Khan and Iqbal 2016; Scicutella et al. 2021). The direct antibacterial effect of organic acid allows the orthophosphoric acid to reduce the $\mathrm{pH}$ of the digesta resulting in the more concentration of the undissociated form of the acids (Dibner and Buttin 2002). Organic acid reduces inside $\mathrm{pH}$ of the bacteria after dissociation and results in death. Organic acids reduce the total microbial load and consequently reduce the subclinical infection leading to improved digestibility and lessened demand of energy by the gut-associated tissue (Khan et al. 2016a). In addition, the low $\mathrm{pH}$ of the upper GIT also favors the antimicrobial activity of the organic acids and helps their absorption through diffusion in the epithelium (Scicutella et al. 2021). In addition, the organic acid in the lower part of the intestines reduces the competition of the host with the microflora resulting in improved digestion (Khan and Iqbal 2016).

\section{Nutrient digestibility}

In a study, Garcia et al. (2007) reported that supplemented with 5000 and 10,000 ppm formic acid produced similar results to avilamycin, which ultimately improved the growth and apparent ileal digestibility. In addition, positive effect on the intestinal mucosa was also observed. Cakir et al. (2008) reported that organic acid supplementation significantly improved duodenal villus height. Chaveerach et al. (2004) revealed that acidified drinking water improved the gut epithelial cells. Runho et al. (1997) reported improved metabolizable energy in broiler fed with $0.5-1 \%$ fumeric acid. Hernandez et al. (2006) reported that the addition of 5 and $10 \mathrm{~g} / \mathrm{kg}$ formic acid has little effect on the ileal digestibility of nutrients. A number of authors have documented
Fig. 2 Mechanism of action of organic acid against bacteria

\section{Undissociated Aceitc acid $\quad$ R-COOH}

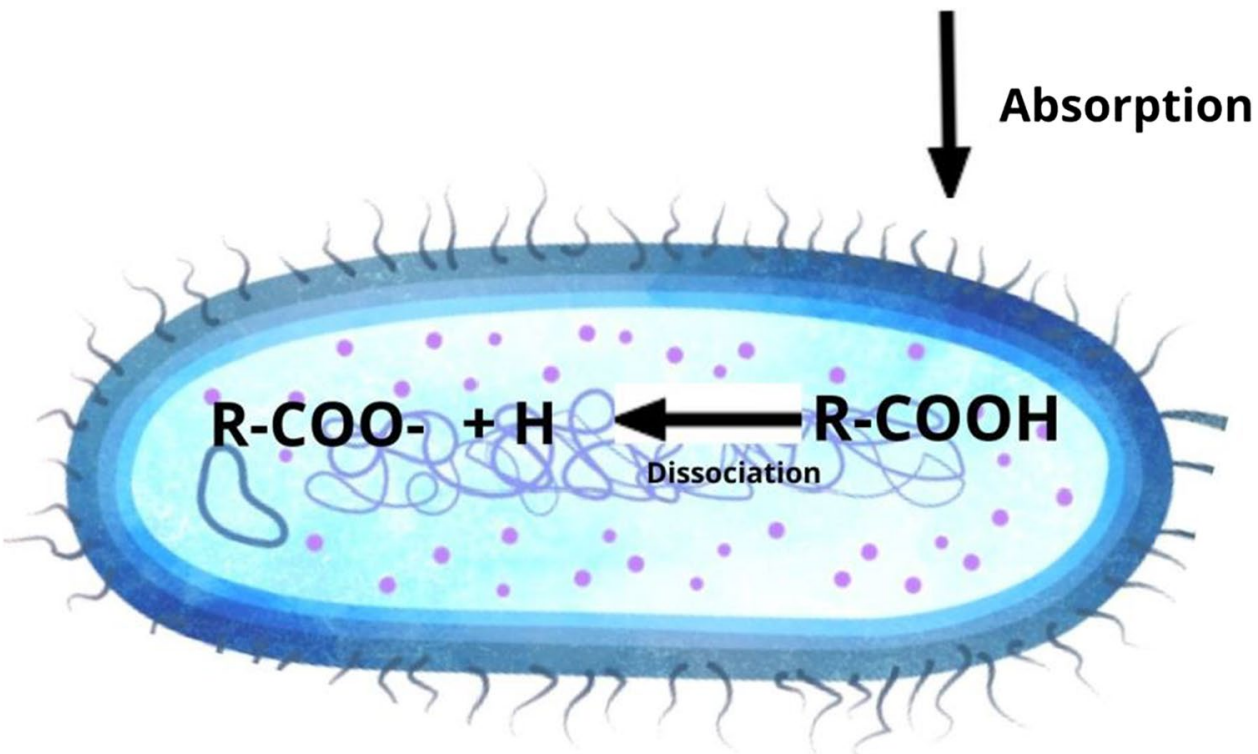


the positive effect of organic acids on the improved digestibility of nutrients in broiler feed (Hernandez et al. 2006; Garcia et al. 2007; Ghazala et al. 2011; Rodjan et al. 2017; Sureshkumar et al. 2021). Organic acid lowers the $\mathrm{pH}$ of the digesta and raises the gastric proteolytic activity (Khan et al. 2016b). The $\mathrm{pH}$ modulation of the specific area of the intestines is another factor which favors the proliferation of the specific microbial population, affecting the digestion and absorption of the nutrients, since most of the pathogenic bacteria reside at a $\mathrm{pH}$ close to 7 (Sureshkumar et al. 2021). In contrast, the beneficial bacteria survive better at a pH 5.8-6.2. Since organic acids lower the $\mathrm{pH}$, so the acidic environment favors the growth of the beneficial bacteria and reduces the population of the pathogenic microbes (Haque et al. 2009). Ultimately, the digestion and absorption of the nutrients are increased in the presence of the beneficial bacteria. The organic acids probably also activate the pepsin activity which causes proteolysis of protein. As a result, the protein contents are broken down into simple peptides which stimulate the release of gastrin and cholecystokinin hormones. In addition, the pancreatic juice is secreted in an organic acid environment containing higher concentrations of procarboxy peptidases, chymotrypsinogen, and trypsin (Adil et al. 2010). The slower rate of the passage of digesta in response to organic acid enhances the absorption of the feed contents from the intestines (Abudabos et al. 2017). In the presence of acidic environment, bacterial metabolites such as ammonia and amines are reduced (Samanta et al. 2010) which enhances the digestibility. The enhanced nutrient digestibility by organic acid is also associated with improvement in the release of digestive enzymes, microbial phytase activity, and increased pancreatic activity in the gut (Hernandez et al. 2006). In the presence of dietary organic acid, the digestibility of minerals, particularly phosphorous and calcium, has been increased probably due to the more effective role of the Lactobacillus spp. in the digestive tract. Chowdhury et al. (2009) reported that phosphorous utilization was increased in response to citric acid supplementation in broilers. Similar results were also reported by some other researchers (Nezhad et al. 2007). Dietary supplementation with mixed organic acid increased the pancreatic activity and boosted the expression of tight junction proteins, resulting in healthier broiler production (Ma et al. 2021). Sorbic acid and fumaric acid were also reported to improve significantly trypsin, lipase, and chymotrypsin activities in the intestine at different stages of growth in broilers (Yang et al. 2018).

Birds are well recognized for their inability to efficiently metabolize fibrous carbohydrates in their diet. Soluble dietary fiber increases digesta viscosity and slows passage rate, ultimately, lowering the absorption of nutrients (Shang et al. 2020). The gut microbiota is crucial in the fermentation of undigested carbohydrates, especially in the caeca. This fermentation produces acetate, propionate, and butyrate, all of which have been shown to enhance avian intestinal morphology, tight junctions, and immunological state CorrêaOliveira et al. (2016). The usage of organic acids has also been linked to improvements in nutritional digestibility, particularly for minerals (Emami et al. 2013).

\section{Immune response}

In modern poultry production, broilers appear to have less resistant immune system. The broilers are expected to produce a high meat yield within a short period of time. The fast growth and efficient feed utilization have resulted in compromised immune status in broiler (Khan et al. 2012a; Ghazvinian et al. 2018). In broilers, it is assumed that there is a close relationship between the immune status and their genetic makeup, resulting in higher susceptibility of compromised immune response compared to the other species of birds (Emami et al. 2013). Since the growth rate in broilers is rapid, however, their immunity level is not developed at the same speed; therefore, they are susceptible to many infectious diseases. This response is more weakened in the absence of antibiotics in broiler feed. Organic acids are capable of modulating the number of pathogenic bacteria and therefore, they might be helpful in improving the immune status of broiler. An improved immune response was reported in broiler chicks fed with different blends of organic acids (Chowdhury et al. 2009; Houshmand et al. 2012; Abbas et al. 2013; Yang et al.2018; Scicutella et al. 2021).

A significant increase in antibody titer was significantly improved in broilers against Newcastle disease in response to organic acid supplementation (Houshmand et al. 2012; Abbas et al. 2013). The improved immunoglobulin status was also found to be raised by the dietary supplementation of organic acid in broilers (Park et al. 2009). Heavier immune organs have also been reported in response of organic acid supplementation (Ghazala et al. 2011). Similarly, improved immune response has also been reported in response to organic acid supplementation in broiler in other studies. The improved immune response of broiler could be due to the increased Lactobacillus spp. population in the gastrointestinal tract, which have a positive effect on the host immune system (Emami et al. 2013). The enhanced immune response of broiler in the presence of sodium butyrate has been attributed to its ability to inhibit NF-kB activation (Zhang et al. 2011). Also, Zhang et al. (2011) reported increased antioxidant activity and reduced oxidant status in broiler fed with sodium butyrate. Different doses of organic acid $(0.2 \%$ and $0.4 \%$ ) blends increased IgG titer (primary and secondary) and humoral immunity to a dose of sheep RBCs and vaccination of bursal disease (IBD) virus and infectious bronchitis (Emami et al. 2013; Emami et al. 2017). Dietary 
supplementation with mixed organic acid improved immunological features in blood and the small intestine, as well as modulated the cecum bacterial population, resulting in healthier broiler development (Ma et al. 2021). Haque et al. (2009) suggested that the citric acid appears to stimulate the nonspecific immunity since it increased lymphocyte number in the lymphoid organs. The methods by which organic acids regulate immunity are unknown, although it is speculated that organic acid causes activation of systemic regulatory $\mathrm{T}$ cells and a reduction in an inflammatory response signal (alpha 1-acid glycoprotein) in broilers following H9N2 vaccination (Lee et al. 2011). Gut-related immunity in response to organic acid supplementation also depends upon particular GIT bacteria, and their association with gutassociated lymphoid tissue (Emami et al. 2017).

\section{Intestinal integrity}

It has been demonstrated that organic acid-supplemented meals protected epithelial cells against disruption by reducing the synthesis of toxins in the gut, resulting in reduced mucosal permeability of the intestines (Kumar et al. 2021). Good intestinal health is the primary requirement in the poultry industry to achieve target feed efficiency and growth rate. The antimicrobial agents reduce the pathogen load and their toxins in the intestines. Short chain fatty acids stimulate healthy tissue turnover and enhance the proliferation of normal crypt cells (Scheppach et al. 1995). Organic acids in different doses and combinations have shown improved villus height, width, crypt depth, and area of ileum, duodenum, and jejunum in broiler (Leeson et al. 2005; Garcia et al. 2007; Panda et al. 2009; Adil et al. 2010; Rodjan et al. 2017; Yang et al. 2018). Recently, Kumar et al. (2021) reported that short chain fatty acids consisting of different blends of organic acid improved the intestinal health in broilers infected with necrotic enteritis. Organic acids stimulate the proliferation of gastrointestinal cells by increasing ileal proglucagon mRNA glucagon-like peptide-2 (GLP-2) and protein expression which can mediate epithelial proliferation of the intestines.

The most acceptable reason of the improved intestinal integrity has been associated with a reduction of the intestinal pathogenic bacteria. The pathogenic bacteria alter the normal microflora and disturb the permeability of the intestines, and thereby facilitate the entry of toxins into the intestines leading to the inflammatory process. Consequently, there is a reduction in the texture of the villus, which ultimately decreases the absorptive capacity of the intestines. The organic acids reduce the number of pathogenic bacteria and their entry into the intestinal mucosa and subsequently the inflammatory process (Hayat et al. 2014; Sultan et al. 2015; Abudabos et al. 2016; Khan et al. 2016b). Some studies also showed no effect on the intestinal health in the diets supplemented with organic acids (Milbradt et al. 2014; Waguespack Levy et al. 2015). Disparity across studies is definitely due to changes in the underlying microbiological challenge and bird performance, as well as discrepancies in organic acids employed, dosage, feed formulations, and other factors that must be taken into account for the optimal field responses.

\section{Conclusion}

Poultry producers are experiencing huge challenges of increasing demand of production and health. It is a wellknown scientific fact that organic acid is a valuable source of potentiating the growth and prevention of some of the infectious diseases. Organic acids could be a good alternative to antibiotics. Organic acids provide a sustainable and potent alternative to maximize future production and health of broiler. The tremendous potential of organic acids could be advanced with the use of modern science and technologies at molecular, biotechnological, and nanotechnological level. The future studies should be directed towards the optimization of the dose, duration, concentration, and exact mechanism of action of organic acids to authenticate and widen the beneficial uses.

Acknowledgements All authors thank the departments involved.

Author contribution Rifat U. Khan, Shabana Naz, Fazal Raziq, Qudratullah, Nazir A. Khan, Vito Laudadio, Vincenzo Tufarelli, Simona Tarricone, and Marco Ragni: conceptualization, writing—review and editing, writing-original draft.

Data availability Not applicable.

\section{Declarations}

Ethical approval Not applicable.

Consent to participate Not applicable.

Consent for publication Not applicable.

Competing interests The authors declare no competing interests.

Open Access This article is licensed under a Creative Commons Attribution 4.0 International License, which permits use, sharing, adaptation, distribution and reproduction in any medium or format, as long as you give appropriate credit to the original author(s) and the source, provide a link to the Creative Commons licence, and indicate if changes were made. The images or other third party material in this article are included in the article's Creative Commons licence, unless indicated otherwise in a credit line to the material. If material is not included in the article's Creative Commons licence and your intended use is not permitted by statutory regulation or exceeds the permitted use, you will need to obtain permission directly from the copyright holder. To view a copy of this licence, visit http://creativecommons.org/licenses/by/4.0/. 


\section{References}

Abbas G, Khan SH, Rehman H (2013) Effects of formic acid administration in the drinking water on production performance, egg quality and immune system in layers during hot season. Avian Biol Res 6:227-232. https://doi.org/10.3184/175815513X13740 707043279

Abd El-Hack ME, Alagawany M, Arif M, Emam M, Saeed M, Arain MA, Siyal FA, Patra A, Elnesr SS, Khan RU (2018) The uses of microbial phytase as a feed additive in poultry nutrition a review. Ann Anim Sci 18:639-658. https://doi.org/10.2478/ aoas-2018-0009

Abdel-Fattah, S., E.-S. M.H, N. El-Medany, \& F. Abdelazeem. 2008. Thyroid activity, some blood constituents, organs morphology and performance of broiler chicks fed supplemental organic acids. Int. J. Poult. Sci. 7: 215-222.https://doi.org/10.3923/ijps. 2008.215.222

Abudabos AM, Alyemni AH, Dafalla YM, Khan RU (2016) The effect of phytogenic feed additives to substitute in-feed antibiotics on growth traits and blood biochemical parameters in broiler chicks challenged with Salmonella typhimurium. Environ Sci Pollut Res Int 23:24151-24157. https://doi.org/10.1007/s11356-016-7665-2

Abudabos AM, Alyemni AH, Dafalla YM, Khan RU (2017) Effect of organic acid blend and Bacillus subtilis alone or in combination on growth traits, blood biochemical and antioxidant status in broilers exposed to Salmonella typhimurium challenge during the starter phase. J Appl Anim Res 45:538-542. https://doi.org/ 10.1080/09712119.2016.1219665

Abudabos AM, Alyemni AH, Dafalla YM, Khan RU (2018) The effect of phytogenics on growth traits, blood biochemical and intestinal histology in broiler chickens exposed to Clostridium perfringens challenge. J Appl Anim Res 46:691-695

Adhikari P, Yadav S, Cosby DE, Cox NA, Jendza JA, Kim WK (2020) Research Note: Effect of organic acid mixture on growth performance and Salmonella typhimurium colonization in broiler chickens. Poult Sci 99:2645-2649. https://doi.org/10.1016/j.psj. 2019.12.037

Adil S, Banday MT, Bhat GA, Mir MS, and Rehman M (2010) Effect of dietary supplementation of organic acids on performance, intestinal, histomorphology, and serum biochemistry of broiler chicken. Veterianry Medicine International 1-7. https://doi.org/ 10.4061/2010/479485

Ahmad M, Chand N, Khan RU, Ahmad N, Khattak I, Naz S (2020) Dietary supplementation of milk thistle (Silybum marianum): growth performance, oxidative stress, and immune response in natural summer stressed broilers. Trop Anim Health Prod 52:711-715. https://doi.org/10.1007/s11250-019-02060-4

Akbar, M. A., B. S. Tewatia, \& S. Kumar. 2018. Effect of dietary supplementation of salts of organic acids on gut morphology and meat quality of broilers. Indian J. Anim. Res. 52: 1727-1731. https://doi.org/10.18805/ijar. B-3448

Alam S, Masood S, Zaneb H, Rabbani I, Khan RU, Shah M, Ashraf S, Alhidary IA (2020) Effect of Bacillus cereus and Phytase on the expression of musculoskeletal strength and gut health in Japanese quail (Coturnix japonica). J Poult Sci 57:200-204. https://doi. org/10.2141/jpsa.0190057

Aljumaah MR, Alkhulaifi MM, Abudabos AM, Alabdullatifb A, ElMubarak AH, Al Suliman AR, Stanley D (2020) Organic acid blend supplementation increases butyrate and acetate production in Salmonella enterica serovar Typhimurium challenged broilers. PLoS ONE 15:e232831-e0232831. https://doi.org/10.1371/ journal.pone. 0232831

Alzawqari MH, Al-Baddany AA, Al-Baadani HH, Alhidary IA, Khan RU, Aqil GM, Abdurab A (2016) Effect of feeding dried sweet orange (Citrus sinensis) peel and lemon grass (Cymbopogon citratus) leaves on growth performance, carcass traits, serum metabolites and antioxidant status in broiler during the finisher phase. Environ Sci Pollut Res Int 23:17077-17082. https://doi. org/10.1007/s11356-016-6879-7

Araujo, R., G. Polycarpo, A. Barbieri, K. Silva, G. Ventura, \& V. C. C. Polycarpo. 2019. Performance and economic viability of broiler chickens fed with probiotic and organic acids in an attempt to replace growth-promoting antibiotics. Braz. J. Poult. Sci. 21.https://doi.org/10.1590/1806-9061-2018-0912

Atapattu NSBM, Nelligaswatt CJ (2005) Effects of citric acid on the performance and the utilization of phosphorous and crude protein in broiler chickens fed on rice by-products based diets. Intern J Poultry Sci 12:990-993

Axel C, Zannini E, Arendt EK (2017) Mold spoilage of bread and its biopreservation: a review of current strategies for bread shelf life extension. Crit Rev Food Sci Nutr 57:3528-3542. https://doi.org/ 10.1080/10408398.2016.1147417

Baghban-Kanani P, Hosseintabar-Ghasemabad B, Azimi-Youvalari S, Seidavi A, Ragni M, Laudadio V, Tufarelli V (2019) Effects of using Artemisia annua leaves, probiotic blend, and organic acids on performance, egg quality, blood biochemistry, and antioxidant status of laying hens. J Poult Sci 56(2):120-127

Banupriya S, Kathirvelan C, Patric Joshua P (2016) Significance of feed acidification in poultry feed. Int J Sci Environ Technol 5:1596-1599

Boroojeni FGA, Mader F, Knorr I, Ruhnke I, Röhe A, Hafeez KM, Zentek J (2014) The effects of different thermal treatments and organic acid levels on nutrient digestibility in broilers. Poult Sci 93:1159-1171

Cakir S, Midilli M, Erol H, Simsek N, Cinar M, Altintas A, Alp H, Altintas L, Cengiz Ö, Antalyali A (2008) Use of combined probiotic-prebiotic, organic acid and avilamycin in diets of Japanese quails. Rev Med Vet 11:565-569

Chand N, Faheem H, Khan RU, Qureshi MS, Alhidary IA, Abudabos AM (2016) Anticoccidial effect of mannanoligosacharide against experimentally induced coccidiosis in broiler. Environ Sci Poll Res 23:14414-14421

Chand N, Shamsullah R, Khan RU, Mobashar M, Naz S, Rowghani I, Khan MA (2019) Mannanoligosaccharide (MOS) in broiler ration during the starter phase: 1 . growth performance and intestinal histomorphology. Pak J Zool 51:173-176

Chand N, Ali P, Alhidary IA, Abelrahman MM, Albadani H, Khan MA, Seidavi A, Laudadio V, Tufarelli V, Khan RU (2021) Protective effect of grape (Vitis vinifera) seed powder and zinc-glycine complex on growth traits and gut health of broilers following Eimeria tenella challenge. Antibiot 10:186. https://doi.org/10. 3390/antibiotics 10020186

Chaveerach P, Lipman LJA, van Knapen F (2004) Antagonistic activities of several bacteria on in vitro growth of 10 strains of campylobacter jejuni/coli. International Journal of Food Microbiology 90:43-50

Chowdhury R, Islam KMS, Khan MJ, Karim MR, Haque MN, Khatun M, Pesti GM (2009) Effect of citric acid, avilamycin, and their combination on the performance, tibia ash, and immune status of broilers. Poult Sci 88:1616-1622. https://doi.org/10.3382/ps. 2009-00119

Corrêa-Oliveira R, Fachi JL, Vieira A, Sato FT, Vinolo MAR (2016) Regulation of immune cell function by short-chain fatty acids. Clin Trans1 Immunol 5:e73. https://doi.org/10.1038/cti.2016. 17

Dhama K, Tiwari R, Khan RU, Chakroborty S, Gopi M, Kathik K, Saminathan M, Desingu PA, Sunkara LT (2014) Growth promoters and novel feed additives improving poultry production and health, bioactive principles and beneficial applications: the trends and advances- a review. Intern J Pharmacol 10:129-159 
Dhama K, Latheefmani SKS et al (2015) Multiple beneficial applications and modes of action of herbs in poultry health and production- a review. Intern J Pharmacol 11:152-176

Dibner JJ, Buttin P (2002) Use of organic acids as a model to study the digestibility, immune response and intestinal morphology of male broilers fed phosphorus deficient diets supplemented with microbial phytase and organic acids. Livest Sci 157:506-513

Emami NK, Naeini SZ, Ruiz-Feria CA (2013) Growth performance, digestibility, immune response and intestinal morphology of male broilers fed phosphorus deficient diets supplemented with microbial phytase and organic acids. Livest Sci 157(2-3):506-513

Emami NK, Daneshmand A, Naeini SZ, Graystone EN, Broom LJ (2017) Effects of commercial organic acid blends on male broilers challenged with E. coli K88: performance, microbiology, intestinal morphology, and immune response. Poult Sci 96:32543263. https://doi.org/10.3382/ps/pex106

Emili Vinolya R, Balakrishnan U, Yasir B, Chandrasekar S (2021) Effect of dietary supplementation of acidifiers and essential oils on growth performance and intestinal health of broiler. J Appl Poult Res 30:100179. https://doi.org/10.1016/j.japr.2021.100179

Fortuoso BF, Dosreis JH, Gebert RR, Barreta M, Griss LG, Casagrande RA, De Cristo TG, Santiani F, Campigotto G, Rampazzo L et al (2019) Glycerol monolaurate in the diet of broiler chickens replacing conventional antimicrobials: impact on health, performance and meat quality. Microb Pathog 129:161-167

Gadde, U., Kim, W.H., Lillehoj, H.S. 2017. Alternatives to antibiotics for maximizing growth performance and feed efficiency in poultry: a review. Animal Health and Research Review.:https:// doi.org/10.1017/S1466252316000207

Galli GM, Aniecevski E, Petrolli TG, Da Rosa G, Boiago MM, Simões CA, Wagner R, Copetti PM, Morsch VM, Araujo DN et al (2021) Growth performance and meat quality of broilers fed with microencapsulated organic acids. Anim Feed Sci Technol 271:114706

García V, Catalá-Gregori P, Hernández F, Megías MD, Madrid J (2007) Effect of formic acid and plant extracts on growth, nutrient digestibility, intestine mucosa morphology, and meat yield of broilers. J Appl Poult Res 16:555-562. https://doi.org/10.3382/ japr.2006-00116

Ghazala AA, Atta AM, Elkloub K, Mustafa MEL, Shata RFH (2011) Effect of Dietary Supplementation of Organic Acids on Performance, Nutrients Digestibility and Health of Broiler Chicks. International of Journal of Poultry Science 10(3):176-184. https://doi.org/10.3923/ijps.2011.176.184

Ghazvinian K, Seidavi A, Laudadio V, Ragni M, Tufarelli V (2018) Effects of various levels of organic acids and of virginiamycin on performance, blood parameters, immunoglobulins and microbial population of broiler chicks. S Afr J Anim Sci 48(5):961-967

Gonzalez-Fandos E, Martinez-Laorden A, Perez-Arnedo I (2020) Combined effect of organic acids and modified atmosphere packaging on listeria monocytogenes in chicken legs. Animals 10(10): 1818

Hafeez A, Shah SAA, Khan RU, Ullah Q, Naz S (2020) Effect of diet supplemented with phytogenics and protease enzyme on performance, serum biochemistry and muscle histomorphology in broilers. J Appl Anim Res 48:326-330. https://doi.org/10.1080/ 09712119.2020.1789648

Hafeez A, Sohail M, Ahmad A, Shah M, Din S, Khan I, Shuib M, Nasrullah W, Shahzada MI, Khan RU (2020) Selected herbal plants showing enhanced growth performance, ileal digestibility, bone strength and blood metabolites in broilers. J Appl Anim Res 48:448-453. https://doi.org/10.1080/09712119.2020.1818569

Hafeez A, Ullah Z, Khan RU, Ullah Q, Naz S (2020) Effect of diet supplemented with essential coconut oil on performance and intestinal injury in broiler exposed to avian coccidiosis. Trop Anim Health Prod 52:2499-2504. https://doi.org/10.1007/ s11250-020-02279-6
Hafeez, A., Iqbal, S., Sikandar, A., Din, S., Khan, I., Ashraf, S., R.U. Khan, Laudadio, V. and Tufarelli, V. 2021. Feeding of phytobiotics and exogenous protease in broilers: comparative effect on nutrient digestibility, bone strength and gut morphology. Agriculture 11(3) https://doi.org/10.3390/agriculture11030228

Haq, I., A. Hafeez, \& R.U. Khan. 2020. Protective effect of Nigella sativa and Saccharomyces cerevisiae on zootechnical characteristics, fecal Escherichia coli and hematopoietic potential in broiler infected with experimental Colibacillosis. Livest. Sci. Volume 239, Article 104119 https://doi.org/10.1016/j.livsci.2020.104119

Haque, M.N., Chowdhury, R., Islam, M.A. AKBAR. 2009. Propionic acid is an alternative to antibiotics in poultry diet. Bangladesh Journal of Anim. Sci. 38: 115-122

Haulisah NA, Hassan L, Bejo SK, Jajere SM, Ahmad NI (2021) High levels of antibiotic resistance in isolates from diseased livestock. Frontiers in Veterinary Science 8:300

Hayat TA, Sultan RU, Khan Khan S, Zahoor ULH, Ullah R, Aziz $\mathrm{T}$ (2014) Impact of organic acid on some liver and kidney function tests in Japanese Quails, Coturnix coturnix japonica. Pakistan J Zool 46:1179-1182

Hernández F, García V, Madrid J, Orengo J, Catalá P, Megías MD (2006) Effect of formic acid on performance, digestibility, intestinal histomorphology and plasma metabolite levels of broiler chickens. Br Poult Sci 47:50-56. https://doi.org/10. 1080/00071660500475574

Houshmand M, Azhar K, Zulkifli I, Bejo MH, Kamyab A (2006) Impact of gut microflora on nutrition and metabolism. J Appl Poultry Res 11:453-463

Houshmand M, Azhar K, Zulkifli I, Bejo MH, Kamyab A (2012) Effects of nonantibiotic feed additives on performance, immunity and intestinal morphology of broilers fed different levels of protein. South African Journal of Animal Science. 42:22-32

Israr M, Chand N, Khan RU, Alhidary IA, Abdelrhman MM, AlBaddani HH, Laudadio V, Tufarelli V (2021) Dietary grape (Vitis vinifera) seeds powder and organic zn-gly chelate complex for mitigating heat stress in broiler chickens: growth parameters, malanodialdehyde, paraoxonase-1 and antibody titre. Agriculture 11:1087. https://doi.org/10.3390/agricultur e11111087

Jabbar A, Tahir M, Alhidary MA, Abdelrahman M, Albaadani H, Khan RU, Selvaggi M, Laudadio V, Tufarelli V (2021) Impact of microbial protease enzyme and dietary crude protein levels on growth and nutrients digestibility in broilers over 15 to 28 days. Animals 11:2499. https://doi.org/10.3390/ani11092499

Jabbar, A., M. Tahir, R.U. Khan \& N. Ahmad. 2021b. Interactive effect of exogenous protease and step-wise increment in dietary crude protein on growth and digestibility indices in broiler chickens during the starter phase. Trop. Anim. Health Prod. (In press): https://doi.org/10.1007/s11250-020-02466-5

Khan SH, Iqbal J (2016) Recent advances in the role of organic acids in poultry nutrition. J Appl Anim Res 44:359-369

Khan RU, Naz S (2013) Application of probiotics in poultry production. World's Poultry Sci J 69:621-632

Khan RU, Naz S, Javadani M, Nikousefat Z, Selvaggi M, Tufarelli V, Laudadio V (2012a) The use of turmeric (Curcuma longa) in poultry diets. World's Poultry Sci J 68(1):97-103

Khan RU, Naz S, Tufarelli V, Laudadio V (2012) Potential applications of ginger (Zingiber officinale) in poultry diet. World's Poultry Sci J 68(2):245-252

Khan RU, Naz S, Nikousefat Z, Tufarelli V, Laudadio V (2012c) Thymus vlugaris: alternative to antibiotics in poultry feed. World's Poultry Sci J 68(3):401-408

Khan RU, Nikosefat Z, Tufarelli V, Naz S, Javdani M, Laudadio V (2012d) Garlic (Allium sativa) supplementation in poultry diet: effect on production and physiology. World's Poultry Sci J 68(3):417-424 
Khan RU, Rahman ZU, Javed I, Muhammad F (2013a) Supplementation of vitamins, probioitics and proteins on oxidative stress, enzymes and hormones in post-moulted male broiler breeder. Archiv Tierzucht 61:607-616

Khan RU, Rahman ZU, Javed I, Muhammad F (2013b) Supplementation of dietary vitamins, protein and probiotics on semen traits and immunohistochemical study of pituitary hormones in zincinduced molted broiler breeders. Acta Histochem 115:698-704

Khan RU, Naz S, Dhama K, Saminathan M, Tiwari R, Jeon GJ, Laudadio V, Tufarelli V (2014a) Modes of action of and beneficial applications of chromium in poultry nutrition, production and health: a review. Intern J Pharmacol 10:357-363

Khan RU, Rahman ZU, Javed I, Muhammad F (2014b) Serum antioxidants and trace minerals as influenced by vitamins, protein and probiotics in male broiler breeders. J Appl Anim Res 42(3):249-255

Khan RU, Rahman ZU, Javed I, Muhammad F (2014c) Effect of vitamins, protein level and probiotics on immune response of molted male broiler breeders. J Anim Physiol Anim Nutr 98(4):620-627

Khan RU, Chand N, Ali A (2016a) Effect of organic acids on the performance of Japanese quails. Pak J Zool 48:1799-1803

Khan RU, Naz S, Dhama K, Kathrik K, Tiwari R, Abdelrahman MM, Alhidary IA, Zahoor A (2016b) Direct-fed microbial: beneficial applications, modes of action and prospects as a safe tool for enhancing ruminant production and safeguarding health. Intern J Pharmacol 12:220-231

Khan A, Tahir M, Alhidary I, Abdelrahman M, Swelum AA, Khan RU (2021) Role of dietary Moringa oleifera leaf extract on productive parameters, humoral immunity and lipid peroxidation in broiler chicks. Biotechnol (in press), Anim

Khan RU, Khan A, Naz S, Ullah Q, Laudadio V, Tufarelli V, Ragni M (2021b) Potential applications of Moringa oleifera in poultry health and production as alternative to antibiotics: a review. Antibiot 10:1540. https://doi.org/10.3390/antibiotics10121540

Koyuncu S, Andersson MG, Löfström C, Skandamis PN, Gounadaki A, Zentek J, Häggblom P (2013) Organic acids for control of Salmonella in different feed materials. BMC Vet Res 9:81

Kumar, A., M. Toghyani, S. K. Kheravii, L. Pineda, Y. Han, R. A. Swick, \& S.-B. Wu. 2021. Organic acid blends improve intestinal integrity, modulate short-chain fatty acids profiles and alter microbiota of broilers under necrotic enteritis challenge. Anim. Nutr. https://doi.org/10.1016/j.aninu.2021.04.003

Lee KW, Lillehoj HS, Jeong W, Jeoung HY (2011) An Avian necrotic enteritis: experimental models, host immunity, pathogenesis, risk factors, and vaccine development Poult. Sci 90:1381-1390

Leeson S, Namkung H, Antongiovanni M, Lee EH (2005) Effect of butyric acid on the performance and carcass yield of broiler chickens. Poultry Sci 84(9):1418-1422

Ma J, Mahfuz S, Wang J, Piao X (2021) Effect of dietary supplementation with mixed organic acids on immune function, antioxidative characteristics, digestive enzymes activity, and intestinal health in broiler chickens. Front. Nutr 8:673316

Madrid J (2007) Effect of formic acid and plant extracts on growth, nutrient digestibility, intestine mucosa morphology, and meat yield of broilers. J Appl Poultry Res 16:555-562

Milbradt EL, Okamoto JCZ, Rodrigues EA, Garcia CLP, Sanfelice RLC, Reattifilho AM (2014) Use of organic acids and competitive exclusion product as an alternative to antibiotic as a growth promoter in the raising of commercial turkeys. Poult Sci 93:1855-1861

Moghadam AN, Pourreza J, Samie AH (2006) Effect of different levels of citric acid on calcium and phosphorus efficiencies in broiler chicks. Pakistan Journal of Biological Science 9:1250-1256

Mortada M, Cosby DE, Shanmugasundaram R, Selvaraj RK (2020) In vivo and in vitro assessment of commercial probiotic and organic acid feed additives in broilers challenged with Campylobacter coli. J Appl Poult Res 29:435-446. https://doi.org/10. 1016/j.japr.2020.02.001

Mushtaq M, Naz S, Khan S, Rahman S, Khan RU (2013) In vivo effect of Berberis lyceum and Silybum marianum on production performance and immune status in broiler chicks. Archiv Tierzucht 56:911-916

Nezhad YE, Shivazad M, Nazeeradl M, Babak MMS (2007) Influence of citric acid and microbial phytase on performance and phytate utilization in broiler chicks fed a corn-soybean meal diet. J Facult Vet Med Univers Tehran 61:407-413

Nguyen DH, Kim IH (2020) Protected organic acids improved growth performance, nutrient digestibility, and decreased gas emission in broilers. Animals 10:416. https://doi.org/10.3390/ani10030416

Nourmohammadi R, Hosseini SM, Farhangfar H, Bashtan M (2012) Effect of citric acid and microbial phytase enzyme on ileal digestibility of some nutrients in broiler chicks fed corn-soybean meal diets. Ital J Anim Sci 11:36-40

Panda A, Rao SR, Raju M, Sunder GS (2009) Effect of butyric acid on performance, gastrointestinal tract health and carcass characteristics in broiler chickens. Asian-Australian Journal of Animal Science 22:1026-1031

Park JH, Park GH, Ryu KS (2009) Effect of feeding organic acid mixture and yeast culture on performance and egg quality of laying hens. Kor J Poult Sci 29:109-115

Pearlin BV, Muthuvel S, Govidasamy P, Villavan M, Alagawany M, Ragab Farag M, Dhama K, Gopi M (2020) Role of acidifiers in livestock nutrition and health: a review. J Anim Physiol Anim Nutr 104(2):558-569

Rao, S.V., M.V.L.N. Raju, A. K. Panda, N. S. Poonam, G. Shyam Sunder, \& R. P. 2009. Sharma. Utilization of sunflower seed meal in Vanaraja chicken diet. Ind J. Poultry Sci. 44: 392-395

Raza T, Chand N, Khan RU, Shahid MS, Abudabos AM (2016) Improving the fatty acid profile in egg yolk through the use of hempseed (Cannabis sativa), ginger (Zingiber officinale), and turmeric (Curcuma longa) in the diet of Hy-Line White Leghorns. Arch Anim Breed 68:183-190

Ricke SC (2003) Perspectives on the use of organic acids and short chain fatty acids as antimicrobials. Poultry Sci 82(4):632-639

Rodjan P, Soisuwan K, Thongprajukaew K, Theapparat Y, Khongthong S, Jeenkeawpieam J et al (2017) Effect of organic acids or probiotics alone or in combination on growth performance, nutrient digestibility, enzyme activities, intestinal morphology and gut microflora in broiler chickens. Journal of Animal Physiology and Animal Nutrition. 102(2):931-940

Rodjan P, Soisuwan K, Thongprajukaew K, Theapparat Y, Khongthong S, Jeenkeawpieam J, Salaeharae T (2018) Effect of organic acids or probiotics alone or in combination on growth performance, nutrient digestibility, enzyme activities, intestinal morphology and gut microflora in broiler chickens. J Anim Physiol Anim Nutr (berl) 102:e931-e940. https://doi.org/10.1111/jpn.12858

Runho RC, Sakomura NK, Kuana S, Banzatto D, Junqueira OM, Stringhini JH (1997) Use of an organic acid (fumaric acid) in broiler rations. Revista Brasileira de Zootecnia 26:1183-1191

Sabour S, Tabeidian SA, Sadeghi G (2019) Dietary organic acid and fiber sources affect performance, intestinal morphology, immune responses and gut microflora in broilers. Anim Nutr 5:156-162. https://doi.org/10.1016/j.aninu.2018.07.004

Samanta, S., S. Haldar, \& T. K. Ghosh. 2010. Comparative efficacy of an organic acid blend and bacitracin methylene disalicylate as growth promoters in broiler chickens: effects on performance, gut histology, and small intestinal milieu. Vet. Med. Inter. 2010.

Scheppach W, Bartram HP, Richter F (1995) Role of short-chain fatty acids in the prevention of colorectal cancer. Eur J Can 31(7-8):1077-1080 
Scicutella F, Mannelli F, Daghio M, Viti C, Buccioni A (2021) Polyphenols and organic acids as alternatives to antimicrobials in poultry rearing: a review. Antibiotics 10:1010. https://doi.org/ 10.3390/antibiotics 10081010

Shah M, Zaneb H, Masood S, Khan RU, Mobashar M, Khan I, Din S, Khan MS, Rehman H, Tinelli A (2020) Single or combined applications of zinc and multi-strains probiotic on intestinal histomorphology of broilers under cyclic heat stress. Prob Antimicrob Prot 12:473-480. https://doi.org/10.1007/s12602-019-09561-6

Shahid, S., N., Chand, R.U. Khan, S.M. Suhail \& N.A. Khan. (2015) Alterations in cholesterol and fatty acids composition in egg yolk of Rhode Island Red x Fyoumi hens fed with hemp seeds (Cannabis sativa L.). J. Chem. Article ID 362936 https://doi.org/10. $1155 / 2015 / 362936$

Shang Q, Wu D, Liu H, Mahfuz S, Piao X (1831) The impact of wheat bran on the morphology and physiology of the gastrointestinal tract in broiler chickens. Animals 2020:10. https://doi.org/10. 3390/ani10101831

Shang QH, Liu SJ, He TF, Liu HS, Mahfuz S, Ma XK, Piao XS (2020) Effects of wheat bran in comparison to antibiotics on growth performance, intestinal immunity, barrier function, and microbial composition in broiler chickens. Poultry Science 99(10):4929-4938

Shuaib, M., Nasrullah, Hafeez, A., Alhidary, I.A., Abdelrahman, M.M, Khan, N.U. and R.U. Khan. 2021a. Dietary fortification of crushed seeds of Bonium persicum on growth performance, apparent ileal digestibility and blood metabolites in broiler chicks during the starter phase. Italian J Animal Sci 2015 https://doi. org/10.1080/1828051X.2020.1861555

Shuaib, M., Nasrullah, Hafeez, M., Alhidary, I., Abdelrahman, M. and R.U. Khan. 2021b. Effect of dietary supplementation of wild Cumin (Bunium persicum) seeds on performance, nutrient digestibility and circulating metabolites in broiler chicks during the finisher phase Animal Biotechnol https://doi.org/10.1080/10495 398.2020.1844222

Sultan A, Ullah T, Khan S, Khan RU (2015) Effect of organic acid supplementation on the performance and ileal microflora of broiler during finishing period. Pak J Zool 47:635-639

Sultan A, Ali R, Khan RU, Khan S, Chand N, Tariq A (2019) Nutritional evaluation of two sorghum varieties in broiler fortified with phytase. Pak J Zool 51:1183-1185

Sureshkumar, S., J. H. Park, \& I. H. Kim. 2021. Effects of the inclusion of dietary organic acid supplementation with anti-coccidium vaccine on growth performance, digestibility, fecal microbial, and chicken fecal noxious gas emissions. Braz. J. Poultry Sci. 23.

Tehseen M, Tahir M, Khan RU, Jabbar A, Ahmad B, Ahsan T, Khan S, Abudabos AM (2016) Additive effect of Nigella sativa and Zingiber officinale herbal mixture on performance and cholesterol profile in broiler. Phil Agr Sci 99:408-413

Tufail M, Chand N, Rafiullah S, Ahmad RU, Khan MM, Naz S (2019) Mannanoligosaccharide (MOS) in broiler diet during the finisher phase: 2 . growth traits and intestinal histomorphology. Pak J Zool 51:597-602

Ullah F, Tahir M, Naz S, Khan NA, Khan RU (2022) In vitro efficacy and ameliorating effect of Moringa oleifera on growth, carcass, stress and digestibility of nutrients in Eschertchia coli-infected broilers. Journal of Applied Animal Research. https://doi.org/10. 1080/09712119.2022.2039156

Vermeulen K, Verspreet J, Courtin C, Haesebrouck F, Ducatelle R, Van Immerseel F (2017) Reduced particle size wheat bran is butyrogenic and lowers Salmonella colonization, when added to poultry feed. Vet Microbiol 198:64-71

Versteegh, H. A. J. \& A. W. Jongbloed. 1999. The effect of supplementary lactic acid in diets on the performance of broilers. ID-DLO Rep. 99-006.

Vogt H, Matthes S, Harnisch S (1981) The effect of organic acids in the rations on the performances of broilers and laying hens. Arch Geflugelkd 45:221-232

Waguespack Levy A, Kessler JW, Fuller L, Williams S, Mathis GF, Lumpkins B, Valdez F (2015) Effect of feeding an encapsulated source of butyric acid (ButiPEARL) on the performance of male Cobb broilers reared to 42 d of age. Poult Sci 94:1864-1870

Yang X, Xin H, Yang C, Yang X (2018) Impact of essential oils and organic acids on the growth performance, digestive functions and immunity of broiler chickens. Anim Nutr 4(4):388-393

Yudiarti T, Isroli I, Yunianto VD (2020) Nutritive and antioxidative properties of some selected agro-industrial by-products fermented with the fungus Chrysonillia crassa as alternative feedstuffs for poultry. J. Phys. Conf. Ser. 1524:012145

Zhang WH, Jiang Y, Zhu QF, Gao F, Dai SF, Chen J, Zhou GH (2011) Sodium butyrate maintains growth performance by regulating the immune response in broiler chickens. Br Poult Sci 52(3):292-301

Publisher's Note Springer Nature remains neutral with regard to jurisdictional claims in published maps and institutional affiliations. 